\title{
STUDI LITERATUR PENGGUNAAN MEDIA SOSIAL TIKTOK SEBAGAI SARANA LITERASI DIGITAL PADA MASA PANDEMI COVID-19
}

\author{
Astrid Kusuma Rahardaya ${ }^{1)}$, Irwansyah' ${ }^{2}$ \\ ${ }^{1}$ Mahasiswa Pascasarjana Ilmu Komunikasi, Fakultas Ilmu Sosial dan Ilmu Politik Universitas Indonesia \\ email: astrid.k01@ui.ac.id \\ ${ }^{2}$ Staf Pengajar Pascasarjana Ilmu Komunikasi, Fakultas Ilmu Sosial dan Ilmu Politik Universitas Indonesia \\ email: irwansyah09@ui.ac.id
}

\begin{abstract}
The use of the internet, including the use of social media, can change communication patterns, culture, and even the acquisition of information in everyday life. This phenomenon shows a complex contribution where there is a link between social media, communication and information acquisition. Various kinds of social media currently exist, one of which is TikTok which is currently popular and used by various groups from early childhood to adulthood. In the use of TikTok social media, in order not to lead to a negatif direction, digital literacy is needed. Especially during the Covid-19 pandemi, the use of the internet, especially social media, including TikTok has increased. This research is a literature study that aims to determine the use of TikTok as a means of digital literacy during the Covid-19 pandemi and how digital literacy is carried out in several countries in the world. In addition, it also discusses digital literacy when viewed from various perspectives. The results show that digital literacy is needed in the use of social media, one of which is TikTok which if not done will have a negatif impact. Digital literacy is also very much needed in various fields and sectors because of its existence which is able to control the public to avoid inaccurate information and cybercrime.
\end{abstract}

Keywords: Social Media, TikTok, Digital Literacy, Pandemi Covid-19

\begin{abstract}
Abstrak
Pemanfaatan internet termasuk penggunaan media sosial dapat mengubah pola komunikasi, budaya, bahkan perolehan informasi dalam kehidupan sehari-hari. Fenomena ini memperlihatkan adanya kontribusi yang kompleks dimana terdapat keterkaitan antara media sosial, komunikasi dan perolehan informasi. Berbagai macam media sosial yang ada pada saat ini, salah satunya adalah TikTok yang mana sedang popular dan digunakan oleh berbagai kalangan dari mulai usia dini sampai dewasa. Dalam penggunaan media sosial TikTok, agar tidak mengarah kearah yang negatif, maka diperlukan literasi digital. Apalagi pada masa pandemi Covid-19 membuat penggunaan internet khususnya media sosial termasuk TikTok semakin meningkat. Penelitian ini merupakan penelitian studi literatur yang bertujuan untuk mengetahui penggunaan TikTok sebagai sarana literasi digital pada masa pandemi Covid-19 dan bagaimana literasi digital yang dilakukan di beberapa negara di dunia. Selain itu, juga membahas mengenai literasi digital jika dilihat dari berbagai perspektif. Hasilnya menunjukkan bahwa literasi digital diperlukan dalam penggunaan media sosial, salah satunya TikTok yang mana jika tidak dilakukan akan menimbulkan dampak negatif. Literasi digital juga sangat diperlukan di berbagai bidang dan sektor karena keberadaannya yang mampu mengontrol masyarakat agar terhindar dari informasi yang kurang akurat dan tindak kejahatan cybercrime.
\end{abstract}

Keywords: Media Sosial, TikTok, Literasi Digital, Pandemi Covid-19

\section{PENDAHULUAN}

Terhitung hingga saat ini pengguna internet di dunia, termasuk Indonesia meningkat cukup signifikan dari tahun sebelumnya. Terhitung saat ini dari laporan yang dipublikasikan oleh We Are Social pada awal tahun Januari 2021, disebutkan bahwa sebanyak 202,6 juta penduduk Indonesia menggunakan internet dari total populasi di Indonesia sejumlah 274,9 juta dan sebanyak 170 juta 
penduduk Indonesia aktif bermedia social. Jumlah ini mengalami peningkatan sebesar $15.5 \%$ dari jumlah pengguna internet pada tahun 2020 dan meningkat sebesar $6.3 \%$ penduduk yang aktif bermedia sosial (Social, 2021). Pada era industri 4.0 ini, menjadikan internet dan media social sebagai media atau sarana untuk berkomunikasi melalui dunia maya. Media ini dijadikan sebagai alat atau sarana bagi setiap individu untuk berkomunikasi dan saling bertukar pesan. Namun, adanya pemanfaatan dari internet dan keberadaan media sosial bisa saja dapat mengubah pola komunikasi, budaya bahkan bahasa yang digunakan untuk berkomunikasi saat ini (Fauzi, 2018).

Fenomena tersebut memperlihatkan adanya kontribusi yang kompleks dimana terdapat keterkaitan antara media dan komunikasi, sehingga secara umum media dapat juga diartikan sebagai alat komunikasi. Media sosial merupakan perkembangan dari teknologi media yang bebasis internet dan memberikan kemudahan bagi masyarakat untuk dapat melakukan komunikasi, partisipasi, saling memberikan dan membagikan informasi serta jaringan secara online, sehingga dapat menyebarkan konten dan informasinya secara luas ke mana saja. Hal ini membuat media sosial semakin banyak diminati oleh berbagai kalangan, terlihat dari semakin berkembangnya media social yang menjadi konsumsi masyarakat, antara lain seperti Facebook, Instagram, Twitter, Snapchat, TikTok, dan lain sebagainya (Khatimah, 2018). Semakin maraknya ragam media sosial menjadi sebab kenaikan penggunaan internet di Indonesia, seperti data yang dilaporkan oleh We Are Social. Jumlah peningkatan yang signifikan ini dapat mengubah pola hidup masyarakat khususnya pada saat pandemi Covid-19, seperti segala hal yang semakin mudah dan modern karena terbantu oleh adanya media ini. Adapun, dalam perkembangannya, salah satu platform media social yang paling menonjol dan diminati berbagai kalangan baik itu anak-anak ataupun remaja adalah TikTok (Adawiyah, 2020).

TikTok merupakan sebuah platform media social yang memungkinkan pemakainya menciptakan video berdurasi 15-60 detik disertai dengan berbagai macam pilihan fitur seperti musik, stiker filter dan beberapa efek kreatif lainnya. Selain itu, para pemakai media social TikTok juga dapat membagikannya ke platform media social lain yang dimiliki. TikTok sendiri diperkenalkan sejak September 2016 dan dipublikasikan oleh sebuah perusahaan asal Tiongkok yang bernama ByteDance. Namun mulanya, ByteDance meluncurkan aplikasi yang bernama Douyin. Kemudian, dikarenakan aplikasi tersebut dalam waktu kurang lebih setahun telah sukses dan berhasil mempunyai lebih dari 100 juta pengguna dengan kurang lebih berhasil menayangkan satu milyar video setiap hari, membuat ByteDance melakukan perluasan ke luar Tiongkok dengan memberi nama aplikasi tersebut menjadi "TikTok" (Adawiyah, 2020). Sampai tahun 2021, berdasarkan data yang diperoleh dari Statista, pengguna aktif TikTok di seluruh dunia diperkirakan hampir mencapai 83 juta pengguna dan sebagian diantaranya berasal dari Indonesia (Tankovska, 2021). Popularitas TikTok ini mengalahkan popularitas dari Instagram yang membutuhkan waktu hampir enam tahun sejak awal untuk mendapatkan pengguna aktif seperti yang berhasil didapatkan oleh TikTok dalam waktu kurang dari tiga tahun. Sedangkan Facebook, membutuhkan waktu lebih dari empat tahun untuk mencapai popularitasnya (Dilon, 2020).

TikTok sendiri banyak digunakan oleh berbagai macam umur, dari anak kecil hingga dewasa. Meskipun sudah diterapkan syarat bahwa aplikasi ini dapat digunakan oleh anak-anak dengan minimal umur 12 tahun, namun tetap saja masih terdapat anak dibawah umur tersebut menggunakannya. Padahal kenyataannya, dikarenakan pengguna TikTok berasal dari 
segala umur, tidak dapat dipungkiri adanya konten-konten negatif dalam TikTok. Terbukti pada tahun 2018, TikTok sempat diblokir di Indonesia selama satu minggu oleh Kominfo karena ditemukan kontenkonten yang bersifat negatif, yang mana dikhawatirkan dapat membahayakan dan membawa pengaruh buruk terhadap anakanak (Adawiyah, 2020). Selain itu, pada tahun 2019 Pemerintah India juga pernah meminta Google dan Apple untuk menghapus TikTok. Hal tersebut terjadi setelah adanya putusan dari pengadilan bahwa terdapat materi-materi yang bersifat negatif yaitu pornografi yang dibagikan melalui TikTok. Adapun, penggunaan TikTok sendiri sempat dilarang di Bangladesh dan dikenakan denda yang cukup besar di Amerika Serikat karena terdapat informasi mengenai anak-anak secara illegal (Dilon, 2020).

Selain penyebaran informasi yang bersifat negatif, misinformasi juga seringkali terjadi pada setiap platform media social. Berkaitan dengan hal tersebut, TikTok telah mengumumkan bahwa TikTok telah mengeluarkan sebuah campaign untuk mendukung meningkatkan literasi digital dan menghentikan penyebaran berita atau laporan yang menyesatkan dalam aplikasinya. Campaign tersebut disebut dengan tagar \#FactCheckYourFeed, yang mana dibuat untuk membantu memberikan bekal pada penggunanya dengan keterampilan yang dibutuhkan untuk dapat terlibat secara kritis dengan konten yang ada dan dapat menavigasi serta menjaga diri dari potensi bahaya penggunaan aplikasi agar senantiasa aman. Campaign ini dilakukan melalui pembuatan konten dengan gaya unik khas TikTok melalui video clip TikTok yang dibuat oleh influencer dan tokoh masyarakat untuk memberikan pelajaran penting mengenai cara mengidentifikasi dan menghindari informasi yang menyesatkan secara online (Hutchinson, 2021).

Literasi digital dikenal sebagai konsep yang mencakup bidang dan kompetensi yang terkait dengan media. Literasi digital merupakan sebuah "akuisisi" kompetensi teknis untuk memakai teknologi informasi dan komunikasi sehingga muncul keterampilan intelektual individu dalam penggunaan teknologi sehari-hari. Istilah literasi digital ini selain mengacu pada literasi media, namun juga pada literasi komputer, yang mana merupakan keterampilan teknologi ditengah muncul dan tumbuhnya "masyarakat pengetahuan" yang menjadi satu kesatuan serta saling terkait untuk dapat sukses di era industri 4.0 atau era digital (Tejedor et al., 2020).

Literasi digital saat ini menjadi pertimbangan yang cukup penting untuk platform media sosial secara khusus dengan sekitar $71 \%$ masyarakat mendapatkan berita dari platform media social. Hal itu membuat berbagai platform media sosial menjadi sumber berita utama dan juga memungkinkan menjadi sebuah media dalam menginformasikan informasi yang salah. Misinformasi juga terjadi pada media sosial TikTok yang baru saja menghapus kurang lebih dari 340,000 video di AS karena melanggar aturan mengenai misinformasi dan digunakan untuk menyebarkan propaganda politik. Maka dari itu, literasi digital sangatlah penting agar tidak terjadi informasi yang keliru. Apalagi pada masa pandemi Covid19 ini, yang mana segala informasi lebih banyak didapatkan secara online (Hutchinson, 2021).

Ketidaksiapan dan ketidakpedulian masyarakat terhadap filterisasi penggunaan media digital atau media sosial, salah satunya pada TikTok membuat adanya penyalahgunaan yang membawa dampak terhadap kehidupan sehari-hari. Berdasarkan hasil survey APJII, bahwa dalam beberapa tahun terakhir, penyebaran informasi negatif media sosial menjadi tidak terkendali. Berbagai informasi dibuat dan disebarkan hanya untuk menaikkan popularitas pembuat atau penyebar informasi. Hal ini menimbulkan keresahan di masyarakat dan pentingnya menyaring informasi- 
informasi tersebut. Adanya media dan literasi digital tentunya membantu setiap individu dalam menyebarkan dan menerima informasi dari berbagai pihak. Hal tersebut membuat media menjadi semakin banyak berhubungan langsung dengan aspek kehidupan masyarakat dalam menyebarkan informasi (Sutrisna, 2020).

Penelitian ini akan mengkaji bagaimana penggunaan TikTok sebagai sarana literasi digital pada masa pandemi Covid-19 dan bagaimana literasi digital yang dilakukan di beberapa negara di dunia. Selain itu, juga membahas mengenai literasi digital jika dilihat dari berbagai perspektif. Dalam penelitian ini, peneliti mengharapkan dapat membantu khalayak khususnya generasi muda pengguna media sosial terutama TikTok agar mampu memakai dan memanfaatkan penggunaannya dengan bijak serta menyaring informasi yang didapatkan. Penelitian ini merupakan studi literatur dengan membandingkan analisis atau temuan dari penelitian terdahulu yang terjadi pada beberapa negara, termasuk Indonesia.

\section{METODE PENELITIAN}

Metode yang digunakan dalam penelitian ini adalah penelitian dengan menggunakan pendekatan kualitatif dengan menerapkan studi meta-analisis untuk membuat tinjauan literatur yang didapat dari beberapa penelitian yang telah dilakukan sebelumnya dan membuat ringkasan temuan dari penelitian terdahulu (Cogaltay \& Karadag, 2015). Kemudian, tinjauan sistematik juga dilakukan dalam penelitian ini guna untuk melakukan pencarian literatur yang komprehensif dari studi individu terdahulu (Crowther et al., 2010).

Peneliti menggunakan metode studi literatur untuk menjawab permasalahan yang diuraikan. Metode ini dipakai guna memberikan ikhtisar komprehensif terhadap penelitian terdahulu mengenai topik yang spesifik dengan menunjukkan kepada para pembaca apa saja yang telah ditemukan oleh peneliti tentang penggunaan TikTok sebagai sarana literasi digital pada masa pandemi Covid-19. Selain itu, peneliti juga memberikan penjelasan literasi digital dari berbagai perspektif, seperti perspektif industri 4.0, perspektif komunikasi, perspektif teknologi, perspektif masyarakat 5.0, dan perspektif masa depan. Berikut merupakan beberapa langkah yang dilakukan dalam penelitian ini antara lain; peneliti mencari dan mengumpulkan berbagai jurnal atau studi terdahulu mengenai literasi digital dan penggunaan TikTok yang terpublikasi lima sampai sepuluh tahun terakhir. Kemudian, mengidentifikasi pemikiran dasar yang digunakan dan hasil temuan dari studi terdahulu. Lalu, temuan-temuan tersebut dianalisis dan ditarik kesimpulan berdasarkan penelitian yang ditinjau (Djamba \& Neuman, 2014).

Studi literatur yang peneliti gunakan dalam penelitian ini adalah studi penelitian terdahulu yang terjadi di beberapa negara dunia seperti Negara Bagian Kemitraan Timur (EaP) yang mana dalam penelitiannya menggunakan metode kualitatif disertai data dengan diimplikasikan serta dipaparkan dalam bentuk research paper (Akhvlediani \& Khutkyy, 2020). Kemudian, pada penelitian yang dilakukan di Spanyol, Italia dan Ekuador menggunakan penelitian kuantitatif dengan penyebaran kuesioner (Tejedor et al., 2020). Lalu, penelitian yang dilakukan di Burgaria, metode penelitian yang digunakan adalah penelitian kuantitatif dengan melakukan survey yang dilakukan pada 29 April - 3 Mei 2020 serta dilakukan analisis dokumen dan Focus Group Discussion (FGD) dan beberapa studi terdahulu lainnya (Milenkova \& Lendzhova, 2021). 


\section{HASIL DAN PEMBAHASAN}

Penelitian ini membahas mengenai penggunaan media sosial, salah satunya TikTok dan literasi digital terutama pada masa pandemi Covid-19 yang juga dibahas dari beberapa perspektif. Istilah Literasi Digital cukup lama muncul dengan ditandai hadirnya literasi media yang mana mengacu pada masyarakat yang menjadi pengguna aktif pada kemampuan penggunaan teknologi yang semakin berkembang. Setiap tahunnya, pengguna internet bertambah dan menunjukkan kemampuan masyarakat akan literasi media yang semain meningkat. Sehingga hal ini mempengaruhi pula pada pesatnya peningkatan literasi digital pada masyarakat. Literasi digital sendiri dapat didefinisikan sebagai sebuah sikap, ketertarikan maupun kemampuan individua tau masyarakat dalam penggunaan teknologi dan pemanfaatan internet melalui akses, pengelolaan, pengintegritasan, analisa, serta evaluasi terhadap informasi guna membangun pengetahuan baru (Potter, 2019).

Kunci utama adanya literasi digital adalah dengan melibatkan kemampuan individu dalam melakukan tindakan secara digital. Masyarakat pada dasarnya telah mengetahui secara umum apa itu penggunaan media internet, namun sayangnya tidak setiap individu dalam masyarakat mampu menggunakan dan memanfaatkan adanya sarana digital ini secara maksimal dikarenakan keterbatasan ilmu pengetahuan yang mereka miliki. Hal tersebut didukung dalam penelitian yang dilakukan di Indonesia oleh Putu Gede Sutrisna pada tahun 2020, banyak kasus dan berita negatif yang muncul pada masa pandemi Covid-19 dikarenakan saat pandemi Covid-19, mulai diberlakukannya belajar dan bekerja dari rumah yang mana kebanyakan waktu dihabiskan dengan berselancar di dunia internet dengan menggunakan teknologi digital yang dipunya. Tingginya penggunaan internet yang terjadi, kebanyakan belum menyeimbangkan kemampuannya dalam memakai media digital untuk kepentingan dalam pengembangan individu dan juga perolehan informasi sehingga membuat penyebaran berita negatif maupun perilaku cyberbullying kerap terjadi di masa pandemi Covid-19 ini. Maka dari itu, dalam penelitian yang dilakukan oleh Sutrisna, ditawarkan "Gerakan Literasi Digital" khususnya "Gerakan Literasi Digital Keluarga dan Gerakan Literasi Digital Masyarakat" di masa pandemi Covid-19. Gerakan ini sebagai bentuk antisipasi semakin menyebarnya informasi negatif dan membantu masyarakat untuk dapat memperoleh informasi serta bacaan yang mempunyai kualitas dengan mengusulkan beberapa kegiatan yang bermanfaat dalam pemanfaatan pemakaian media digital, salah satunya pada media sosial (Sutrisna, 2020).

Di tengah kondisi pandemi Covid-19, masyarakat perlu sadar bahwa keberadaan literasi digital penting adanya. Individu yang mampu melakukan literasi digital sudah dipastikan akan mampu berpartisipasi dengan baik di dunia yang semakin modern ini. Selain itu, dengan adanya literasi digital masyarakat akan mampu mengantisipasi penyebaran informasi negatif pada masa pandemi ini (Sutrisna, 2020). Literasi juga disebut sebagai suatu kemampuan dalam menulis dan membaca namun kemampuan tersebut dialihkan pada media digital. Manfaat dari adanya literasi digital ini akan memberikan penambahan pembendaharaan kata, mengoptimalisasi kinerja otak, mendapat wawasan dan informasi baru secara cepat dan tepat, kemampuan interpersonal yang baik, mampu memahami informasi dengan cepat, meningkatkan kualitas verbal, meningkatkan kemampuan analisa dan berfikir, juga meningkatkan kemampuan dalam merangkai kata (Sumiati \& Wijonarko, 2020). Adanya literasi digital ditengah masyarakat sangat penting adanya guna membantu pemanfaatan internet dan teknologi informasi agar lebih maksimal dan bermanfaat. Maka dari itu, 
saat ini pemerintah berinisiatif untuk melakukan edukasi teradap masyarakat dengan menitikberatkan pada pentingnya penggunaan media sosial dengan bijak, kreatif, dan inovatif. Berkaitan dengan hal tersebut, Kemkominfo bekerja sama dengan Kemendikbud melakukan berbagai upaya seperti adanya edukasi online khusus untuk masyarakat yang diselenggarakan di berbagai platfrom internet sebagai bentuk implementasi dari literasi digital. Adapun, salah satu faktor pendukung utama dalam terwujudnya agenda transformasi digital ini adalah dengan menciptakan masyarakat digital yang memegang peranan penting didalamnya (Alam, 2021).

Selain di Indonesia, merebaknya kasus pada masa pandemi Covid-19 ini juga menjadi tantangan bagi beberapa negara-negara tetangga, seperti di Negara Bagian Kemitraan Timur (EaP) yaitu Armenia, Azerbajian, Belarus, Georgia, Moldova, dan Ukraina. Literasi digital dilakukan untuk melanjutkan aktivitas online sebagaimana diberlakukannya sejumlah layanan seperti kerja jarak jauh dan pembelajaran online selama masa pandemi berlangsung. Literasi digital ini diberlakukan dengan program yang bernama "EU Programmes" yang diimplementasikan sesuai dengan beberapa wilayah, seperti EAPConnect, EU4Digital, dan EU4Youth. Program ini dibuat sebagai bentuk literasi digital karena semenjak pandemi Covid-19, disinformasi dan berita palsu cepat menyebar di negara EaP. Namun ditemukan, pada penerapannya terjadi kesenjangan yang terjadi berdasarkan usia, pendidikan dan lokasi tempat tinggal. Remaja yang berpendidikan tinggi yang tinggal di perkotaan lebih dapat melakukan literasi digital dengan lebih baik dibandingkan dengan orang tua yang kurang berpendidikan dan tinggal di pedesaan, yang mana lebih berjuang untuk melakukan literasi digital dan membedakan informasi yang negatif atau mana yang benar. Maka dari itu, pengkomunikasian EU Programmes yang secata massif diperlukan agar pendekatan literasi digital ini tersebar secara merata (Akhvlediani \& Khutkyy, 2020).

Penelitian mengenai literasi digital terhadap penggunaan media sosial juga dilakukan oleh Milenkova dan Lendzhova pada tahun 2021 di Bulgaria, yang mana dilakukan sebagai praktik dalam lintasan pandemi global yang berkontribusi pada pemahaman dan control sosial dalam penggunaan teknologi digital. Hal tersebut dilakukan karena akibat dari pandemi Covid-19, krisis dalam keluarga masyarakat Bulgaria meningkat. Kehidupan keluarga jadi lebih bergantung pada penggunaan teknologi digital terutama media sosial dan konflik yang muncul lebih bersifat kepada simbolis virtual daripada fisik. Keluarga Bulgaria tampaknya kehilangan kendali atas penggunaan teknologi digital terutama yang dilakukan oleh anak-anaknya. Situasi ini membuat Bulgaria menerapkan literasi digital dengan mengadakan pelatihan online yang memberikan pembelajaran dan pengetahuan mengenai penggunaan digital dan bagaimana menyikapinya selama masa pandemi Covid-19 (Milenkova \& Lendzhova, 2021).

Tidak jauh berbeda, penelitian yang dilakukan oleh Santiago Tejedor, et al. pada tahun 2020 yang membicarakan mengenai literasi digital yang dilakukan di Spanyol, Italia dan Ekuador disebutkan bahwa pandemi Covid-19 memang sangat memberikan dampak yang cukup signifikan terhadap penggunaan teknologi digital. Sistem pendidikan juga terdampak dan harus menghadapi banyak perubahan. Pada penelitian ini, pengimplementasian dari literasi digital dilakukan pada ranah pendidikan yang mana diimplementasi melalui scenario pembelajaran baru dan memberikan pengajaran mengenai pembelajaran digital (Tejedor et al., 2020).

Saat ini, kita sedang berada dalam era revolusi industri keempat atau industri 4.0 yang ditandai dengan adanya fenomena penggunaan teknologi secara massif 
dengan berbasis teknologi informasi dan internet. Pada era ini, segala hal menjadi cepat dan cenderung mudah didapatkan sampai timbul dampak menurunnya budaya baca karena banyak kegiatan masyarakat yang bergantung pada penggunaan gadget dan internet. Apalagi ditambah dengan situasi pandemi Covid19 yang mengubah segala hal yang biasa dilakukan konvensional menjadi online. Literasi digital dipandang sangat perlu dan memberikan kekuatan pada penggunanya agar mampu mengikuti perubahan yang ada (Tarigan \& Takari, 2019). Literasi digital dalam perspektif industri 4.0 sendiri lebih menekankan bagaimana menyikapi dan menfilterisasi penggunaan digital dengan berbagai macam cara, beberapa diantaranya dengan membuat modul elearning atau dengan adanya platformplatform pembelajaran yang tersedia secara bebas, seperti podcast, blog, website atau media sosial yang banyak digunakan salah satunya dengan TikTok. Cara tersebut dapat dilakukan literasi digital dan terbukti efektif dalam penerapannya. Hal ini didukung juga oleh penelitian yang dilakukan oleh Mezia Kemala Sari pada tahun 2021, yang mana dinyatakan bahwa hal diatas terbukti untuk peningkatan pengetahuan dan sadar akan literasi digital khususnya pada masa Pandemi Covid-19 (Sari, 2021).

Dalam perspektif komunikasi dan teknologi adanya literasi digital terhadap media sosial ini justru menjadi sebuah tantangan. Dengan hadirnya kecanggihan teknologi yang mana dapat kita gunakan kapan saja, membuat kita dapat mengetahui segala hal dengan akses yang mudah dengan satu kali klik. Dimana pada umumnya individu dan masyarakat Indonesia khususnya generasi muda masih membutuhkan pengawasan dan perhatian dari orang tua, guru atau pengajar maupun peran serta dari pemerintah karena kondisi yang masih labil dalam menerima informasi atau konten secara mentah dari teknologi digital khususnya media social yang mana juga akan berpengaruh pada bagaimana perilaku mereka (Restianty, 2018). Selain itu, munculnya berbagai konten di media sosial baik yang berbau positif maupun konten yang bersifat negatif dan berisi berita kebohongan membuat literasi digital pada kemajuan teknologi informasi dan komunikasi sangat dibutuhkan untuk dijadikan sarana edukasi bagi setiap individu dalam menggunakan media sosial. Generasi milenial tumbuh dengan akses yang tidak terbatas dalam kemajuan teknologi sehingga berpengaruh terhadap gaya berfikir mereka yang berbeda satu dengan lainnya. Belum lagi kurangnya sosialisasi antar individu karena bentuk interaksi pada zaman sekarang dilakukan secara digital sehingga sangat dibutuhkan pemahaman literasi digital, yang dianggap sama pentingnya dengan berbagai pemahaman ilmu lainnya karena berkaitan dengan ini, keberadaan dan peran serta orang tua maupun pendidik menjadi penting agar sadar dan melek terhadap literasi digital (Fitriani \& Azis, 2019).

Menurut perspektif masyarakat 5.0 pada zaman digital seperti ini, adanya literasi digital pada perkembangan media sosial memberikan pengaruh baik karena membantu manusia dalam menyelesaikan setiap tugas dan kewajiban sehari-harinya. Masyarakat yang mampu menguasai literasi digital maka mereka akan mampu memanfaatkan informasi dalam kanal digital. Literasi digital dirasakan manfaatnya oleh seluruh masyarakat karena mampu menghemat waktu yang digunakan, membantu proses pembelajaran atau kegiatan belajar dan mengajar menjadi lebih cepat, menghemat pengeluaran uang untuk beberapa hal namun juga sekaligus meberikan lonjakan pengeluaran yang sangat tinggi dimana harus menyediakan gadget dan kuota untuk mengakses internet. Selain itu, masyarakat juga merasakan tantangan yang harus dihadapi dengan sikap bijaksana agar tidak terjadi disharmoni dan tidak keseimbangan dalam literasi digital (Tarigan \& Takari, 2019). 
Salah satu tantangan yang harus dihadapi dalam penggunaan teknologi digital khususnya media sosial ini adalah cybercrime. Munculnya berbagai kasus cybercrime maupun kejahatan lainnya, menjadi bukti bahwa sangat rentan terjadi pengaruh negatif dari media sosial. Kecakapan dalam literasi digital termasuk salah satu dari upaya preventif serta edukatif untuk mengurangi dampak maupun pengaruh negatif dari media sosial. Adanya literasi digital ini juga tentunya membantu masyarakat agar tidak mudah tertipu dan termakan oleh jebakan oknum-oknum jahat yang melakukan cybercrime. Masyarakat yang memiliki kemampuan dalam literasi digital, nantinya mereka akan memiliki kemampuan dalam memahami dan menggunakan informasi yang didapatkan dari berbagai macam bentuk dan didapat dari sumber yang beragam dan berasal dari komputer. Maka dari itu, literasi digital bagi masyarakat ini sangat penting adanya untuk menghadapi pesatnya perkembangan teknologi yang semakin maju dan tidak bisa dibatasi. Adanya literasi digital ini juga memberikan daya kemampuan yang kritis dan kreatif serta memiliki pola pemikiran yang berbeda dan beragam karena luasnya dan tidak terbatasnya tempat untuk mendapatkan pengetahuan (Karaman et al., 2021).

Menurut penelitian yang dilakukan oleh Takari dan Tarigan pada tahun 2019 dinyatakan bahwa masa depan akan ditandai dan muncul semakin kompleksnya kebutuhan dan tuntutan dari masyarakat dalam menjalani kehidupan sehari-hari. Hal tersebut juga berdampak dengan semakin meningkatnya penggunaan teknologi dengan kecanggihan telah semakin berinovasi Dalam perspektif masa depan, dilihat dari bagaimana digital membantu masyarakat dalam berbagai hal, maka hal ini tentunya berdampak pada masa depan masyarakat nanti yang juga akan lebih memberikan berbagai sistem yang sangat membantu. Maka dalam pengaplikasiannya diperlukan terlebih dahulu kesiapan mental dan literasi digital yang baik dalam menghadapi masa depan dengan segala kecanggihannya. Saat setiap kegiatan berubah dari manual menjadi komputerisasi, segala hal menjadi mudah namun berdampak pada tingkat kemalasan yang tinggi sehingga diperlukan juga proses adaptasi yang baik agar manusia tidak kehilangan fitrahnya (Tarigan \& Takari, 2019). Apalagi dengan kehadiran $5 \mathrm{G}$ yang akan memberikan kecepatan dan keandalan dalam peningkatan jaringan teknologi digital (Deloitte, 2020).

\section{Penggunaan Media Sosial TikTok Sebagai Sarana Literasi Digital}

Literasi digital pada saat ini lebih digunakan pada pemakaian media sosial. Media sosial yang ada meliputi Facebook, Instagram, Path, Youtube, dan yang sedang popular yaitu TikTok. Pengetahuan yang kurang tentang bagaimana bersikap dengan penggunaan media sosial TikTok dan ketransparan informasi yang terdapat di media sosial TikTok seringkali memberikan dampak negatif bagi penggunanya, yang mana kebanyakan adalah generasi muda. Apabila penggunanya tidak memiliki kemampuan dalam memfiltrasi dan kemampuan literasi digital maka hal tersebut dapat menimbulkan permasalahan. Salah satu yang terjadi adalah penyebaran informasi negatif atau bahkan hoax. Penyebaran tersebut akan lebih mudah terjadi apabila penggunanya sudah semakin banyak dan tersebar diseluruh penjuru wilayah. Belum lagi bantuan teknologi yang memutakhirkan berbagai fitur di TikTok seperti unggahan video yang tidak sesuai dengan berita yang disampaikan atau fakta sebenarnya sehingga menjadikan video tersebut sebagai pusat pemberian berita hoax. Literasi digital sangatlah diperlukan pada masa ini, agar setiap unggahan yang dibagikan di TikTok menjadi bermanfaat dan penggunaannya tidak menimbulkan banyak masalah. Pemilahan informasi secara cerdas juga diperlukan agar tidak 
terjebak pada berita negatif dan berita yang bersifat bohong, karena jika terus terjadi, bisa saja hal ini merubah pola pikir setiap penggunanya yang masih awam akan penggunaan TikTok (Silvana \& Darmawan, 2018).

Di Indonesia sendiri, pengguna TikTok menempati peringkat kedua setelah Youtube. TikTok memiliki peringkat yang sangat jauh diatas jika dibandingkan dengan pengguna Instagram di Indonesia. TikTok sendiri merupakan sebuah platform yang dapat membuat atau membagikan video dengan menggunakan backsound musik yang populer digunakan dan dapat pula berisi video klip, dan videovideo pendek, atau potongan film serta berbagai video pendek yang sengaja diunggah dengan maksud untuk berbagi agar mendapatkan jumlah view, karena semakin banyak jumlah penonton semakin banyak pula popularitas yang didapatkan dan kepopuleran semakin tinggi. Dalam penelitian yang dilakukan oleh Sari, Wafa dan Humaidi pada tahun 2020, menjelaskan bahwa TikTok telah menjadi bagian dari kebiasaan atau gaya hidup mahasiswa yang bertindak sebagai digital natif. Media Sosial TikTok sendiri memberikan dampak positif maupun negatif dalam penggunaannya, yang mana dampak positif yang didapatkan adalah timbulnya rasa percaya diri dan meningkatkan kreatifitas pada saat melakukan ide baru saat membuat video untuk diunggah. Kemudian, untuk dampak negatifnya adalah menjadi candu dan cenderung mengabaikan hal lain yang lebih bersifat penting dibanding mengakses media sosial TikTok. Selain itu, tren masa kini juga menjadi factor meningkatnya Pengguna TikTok di Indonesia (Sari et al., 2020). Penggunaan TikTok yang semakin mendarah daging di berbagai kalangan juga tentunya dapat mempengaruhi kepribadian seseorang seiring dengan intensitas penggunaanya yang semakin tinggi. Apabila pengguna atau individu tersebut tidak melakukan filtrasi ataupun bahkan sama sekali tidak memiliki kemampuan dalam literasi digital yang mereka butuhkan, maka perubahan karakter ini akan menjadi hal yang semakin merugikan bagi mereka karena kemungkinan terpapar hal-hal negatif akan semakin tinggi. Maka dari itu, kesadaran diri sendiri sangatlah dibutuhkan untuk menyikapi hal tersebut (Damayanti, 2021).

Dalam penggunaan media social TikTok, diperlukannya mengedukasi penggunanya sebagai bentuk literasi digital. Hal ini disebutkan dalam penelitian yang dilakukan oleh Oktaheriyani, Wafa, dan Shadiqin yang dilakukan pada tahun 2020 menjelaskan bahwa pemberian edukasi penting untuk dilakukan dan diberikan kepada para pengguna TikTok agar tidak membuat konten-konten yang bersifat negatif dan melanggar aturan. Selain itu agar dalam penggunaannya, konten di TikTok tidak hanya sebuah media untuk menunjukan tarian-tarian saja melainkan juga memberikan konten video yang positif dengan memberikan informasi serta pengetahuan baru (Oktaheriyani et al., 2020). Penggunaan media sosial TikTok dalam masa pandemi yang menjadikannya sebagai platform media sosial terpopuler juga sangat lekat dengan kehidupan manusia mengingat intensitas penggunaannya yang semakin tinggi membuat seluruh pengguna dan masyarakat diwajibkan untuk memiliki kemampuan dalam melakukan literasi digital, yaitu dengan memilah berbagai informasi dan data yang masuk agar nantinya dapat menghasilkan sistem informasi yang baik dalam penggunaannya. Hal ini juga disampaikan oleh Ioana Literat dalam penelitiannya pada tahun 2021 dimana TikTok bahkan menjadi jendela dalam berliterasi untuk para siswa. Mereka belajar banyak hal yang belum didapatkan sebelumnya di kehidupan nyata. Dimana mereka akan mampu melihat berbagai sisi di dunia dan juga akan melatih bagaimana mereka memilih untuk menyimpan apa yang mereka lihat atau hanya mengabaikannya 
sebagai apa yang tidak penting (Literat, 2021).

\section{SIMPULAN}

Literasi digital sangatlah berkaitan
erat dengan semakin beragamnya teknologi saat ini. Berbagai sistem informasi dan komunikasi di era industri yang sangat pesat ini memberikan tantangan kepada para penggunanya untuk mampu menggunakan internet khususnya media sosial dengan bijak. Hal inilah yang disebut dan didefinisikan sebagai literasi digital. Dilihat dari berbagai perspektif, adanya literasi digital ini mampu mendampingi dan membantu masyarakat dalam melakukan kontrol pada dirinya saat menggunakan media sosial, salah satunya penggunaan media sosial TikTok.

TikTok dalam penggunaannya cenderung memberikan dampak negatif dengan hadirnya berbagai macam konten yang masuk termasuk berita-berita negatif maupun informasi hoax, sehingga literasi digital sangatlah dibutuhkan agar penggunanya lebih bijak dalam menggunakannya. Apalagi semenjak pandemi Covid-19 melanda, penggunaan internet khususnya media sosial termasuk TikTok meningkat pesat sehingga munculna berita ataupun informasi tersebut. Orang dewasa yang berada didekat anak usia dini yang sudah mengenal TikTok disarankan untuk mengawasi dan melakukan filter terhadap berbagai data yang masuk dengan tidak menelannya secara begitu saja. Berbagai macam karakteristik pengguna TikTok yang lebih banyak berasal dari generasi muda meningkatkan pentingnya melakukan dan memiliki kesadaran akan literasi digital pada saat menggunakan media sosial ini.

\section{UCAPAN TERIMA KASIH}

Peneliti mengucapkan puji syukur kepada Allah SWT karena berkat Rahmat dan karunia-Nya, penulis dapat menyelesaikan artikel jurnal ini. Penulis juga mengucapkan terima kasih yang sebesar-besarnya kepada dosen pengampu, yaitu Dr. Irwansyah, S.Sos., M.A yang telah membantu penulis dalam menyelesaikan artikel jurnal ini.

\section{DAFTAR PUSTAKA}

Adawiyah, D. P. R. (2020). Pengaruh Penggunaan Aplikasi TikTok Terhadap Kepercayaan Diri Remaja di Kabupaten Sampang. Jurnal Komunikasi, 14(2), 135-148. https://doi.org/10.21107/ilkom.v14i2 .7504

Akhvlediani, T., \& Khutkyy, D. (2020). Digital Literacy in times of the COVID-19 in the Eastern Partnership Countries. Civil Society Forum. https://eap-csf.eu/wpcontent/uploads/Digital-Literacy-intimes-of-the-Covid-19-in-theEastern-Partnership-Countries.pdf

Alam, S. (2021). Literasi Digital Sebagai Dasar Penggunaan Media Sosial. Diperoleh dari situs: https://rri.co.id/humaniora/tren/1008 000/literasi-digital-sebagai-dasarpenggunaan-media-sosial

Cogaltay, N., \& Karadag, E. (2015). Introduction to Meta-Analysis (pp. 19-28). https://doi.org/10.1007/9783-319-14908-0_2

Crowther, M., Lim, W., \& Crowther, M. A. (2010). Systematic review and metaanalysis methodology. Blood, 116(17), 3140-3146. https://doi.org/10.1182/blood-201005-280883

Damayanti, A. (2021). Pengaruh Selebgram Terhadap Kemampuan Literasi Digital. ITB, February.

Deloitte Insights. (2020). Technology, Media, and Telecommunications Predictions 2020. Deloitte's Technology, Media, and 
Telecommunications (TMT), 1-118.

Dilon, C. (2020). Tiktok influences on teenagers and young adults students: The common usages of the application tiktok. American Scientific Research Journal for Engineering, Technology, and Sciences, 68(1), 132-142.

Djamba, Y. K., \& Neuman, W. L. (2014). Social Research Methods: Qualitative and Quantitative Approaches. In Teaching Sociology (Vol. 30, Issue 3). https://doi.org/10.2307/3211488

Fauzi, R. (2018). Perubahan Budaya Komunikasi pada Pengguna Whatsapp di Era Media Baru. JIKE : Jurnal Ilmu Komunikasi Efek, 1(1). https://doi.org/10.32534/jike.v1i1.44

Fitriani, Y., \& Azis, I. A. (2019). Literasi Era Revolusi Industi 4.0. Prosiding SENASBASA, 1, 100-104.

Hutchinson, A. (2021). TikTok Launches New \#FactCheckYourFeed Initiative to Promote Digital Literacy. Diperoleh dari situs: https://www.socialmediatoday.com/n ews/tiktok-launches-newfactcheckyourfeed-initiative-topromote-digital-litera/600168/

Karaman, J., Widaningrum, I., \& Setyawan, M. B. S. (2021). Penerapan Model Literasi Digital Berbasis Sekolah Untuk Membangun Konten Positif Pada Internet. Aksiologiya: Jurnal Pengabdian Kepada Masyarakat, 5(1), 19-21.

Khatimah, H. (2018). Posisi Dan Peran Media Dalam Kehidupan Masyarakat. Tasamuh, 16(1), 119138.

https://doi.org/10.20414/tasamuh.v1 $6 \mathrm{i} 1.548$

Literat, I. (2021). "Teachers Act Like We're Robots": TikTok as a Window Into Youth Experiences of Online Learning During COVID-19. AERA
Open, 7(1), 233285842199553. https://doi.org/10.1177/23328584219 95537

Milenkova, V., \& Lendzhova, V. (2021). Digital Citizenship and Digital Literacy in the Conditions of Social Crisis. MDPI, 10(40). https://doi.org/10.3390/computers 10 040040

Neuman, W.L. (2014). Social Research Methods: Qualitative and Quantitative Approaches 7th Edition. Pearson.

Oktaheriyani, D., Wafa, M. A., \& Shadiqien, S. (2020). MEDIA SOSIAL TIKTOK ( Studi Pada Mahasiswa Fakultas Ilmu Sosial dan Ilmu Politik UNISKA MAB Banjarmasin ). Uniska Banjarmasin. http://eprints.uniska-

bjm.ac.id/id/eprint/3504

Restianty, A. (2018). Literasi Digital, Sebuah Tantangan Baru Dalam Literasi Media. Jurnal Gunahumas, 1(1), $\quad$ 72-87. https://ejournal.upi.edu/index.php/gu nahumas/article/view/28380

Sari, Miranda Febriyani Wafa, Ali Humaidi, A. (2020). Mahasiswa Sebagai Digital Native yang Menggunakan Media Sosial Tiktok menjadi Gaya Hidup. EPrints Uniska, 2001(32), 1-9.

Sari, M. K. (2021). The Impacts of Covid19 Pandemy in Term of Technology Literacy Usage on Students Learning Experience. Jurnal Sosial Humaniora, $\quad 0(0), \quad 43$. https://doi.org/10.12962/j24433527.v $0 \mathrm{i} 0.8348$

Silvana, H., \& Darmawan, C. (2018). Pendidikan Literasi Digital Di Kalangan Usia Muda Di Kota Bandung. Pedagogia, 16(2), 146. https://doi.org/10.17509/pdgia.v16i2. 11327 
Sumiati, E., \& Wijonarko. (2020). Manfaat Literasi Digital Bagi Masyarakat Dan Sektor Pendidikan Pada Saat Pandemi Covid-19. Buletin Perpustakaan Universitas Islam Indonesia, 3(2), 65-80.

Sutrisna, I. P. G. (2020). Gerakan Literasi Digital Pada Masa Pandemi Covid19. Stilistika: Jurnal Pendidikan Bahasa Dan Seni, 8(2), 268-283. https://doi.org/10.5281/zenodo.3884 420

Tankovska. (2021). TikTok- Statistics \& Facts. Diperoleh dari situs: https://www.statista.com/topics/6077 /TikTok/

Tarigan, K., \& Takari, M. (2019). Budaya dalam literasi digital pada era industri 4.0 dan. Magister Seni Usu, 1-7.

Tejedor, S., Cervi, L., Pérez-Escoda, A., \&
Jumbo, F. T. (2020). Digital literacy and higher education during COVID19 lockdown: Spain, Italy, and Ecuador. Publications, 8(4), 1-17. https://doi.org/10.3390/publications8 040048

Potter, J. (2019). Media Literacy. Los Angeles: Sage Publications.

We Are Social. (2021). Digital 2021. Diakses melalui situs: https://datareportal.com/reports/digit al-2021-indonesia 